Article

\title{
Public Diplomacy and the Clash of Satellites
}

\author{
Marwa Fikry Abdel Samei \\ Political Science Department, Cairo University, 12613 Giza, Cairo, Egypt; E-Mail: marwa_mfikry@hotmail.com
}

Submitted: 1 July 2015 | Accepted: 23 November 2015 | Published: 4 May 2016

\begin{abstract}
The communication revolution has shifted the paradigm of diplomacy by emphasizing the role of public diplomacy, at the same time complicating the environment within which state-managed public diplomacy is conducted. The rise of regional media has provided weaker states with opportunities to challenge the monopoly of information on the part of the more powerful states. Al-Hurra, the American sponsored channel to the Arab World, stands as evidence of the challenges facing US policies in this part of the world because of the influential role of regional media. It was particularly Al-Jazeera that transformed the media sphere in the Arab World as well as globally in what became known as "Al-Jazeera effect". The paper argues that identity presentation plays a major role in determining performance of the public diplomacy of the media.
\end{abstract}

\section{Keywords}

Al-Hurra; Al-Jazeera; communication revolution; counter-hegemonic discourse; Gaza War; hegemony; identity representation; public diplomacy; regional media

\section{Issue}

This article is part of the issue "International Broadcasting and Public Diplomacy in the 21st Century", edited by Gary D. Rawnsley (Aberystwyth University, UK).

(C) 2016 by the author; licensee Cogitatio (Lisbon, Portugal). This article is licensed under a Creative Commons Attribution 4.0 International License (CC BY).

\section{Introduction}

The American funded TV channel to the Middle EastAl-Hurra-went on air with a specific mission in mind: challenging Al-Jazeera's (the Qatari channel) predominance and winning Arabs' hearts and minds. According to many American officials, there was a need to counter- balance "biased" Arab media. For example, in his 2004 State of the Union address, President George W. Bush announced the launch of Al-Hurra in order to "cut through the barriers of hateful propaganda" (cited in Cochrane, 2004). However, the US public diplomacy mission was not very successful. Unlike Al-Jazeera, AlHurra was never the "channel to go to" for the majority of Arabs. Not only did it fail to challenge Al-Jazeera's supremacy, but it also lagged behind other Arab channels. Subsequent results of Zogby's and the University of Maryland's poll $(2008,2009,2011)$ showed that AlJazeera remained the most watched news channel for Arab viewers. In 2008, the polls found that after five years of being on air, Al-Hurra was the preferred news channel for only $2 \%$ of Arab viewers.
The question then becomes how do regional satellite media challenge the way the US conducts its public diplomacy in the Arab world? What is the difference between Al-Jazeera and Al-Hurra with regard to their media messages? This study argues that Al-Jazeera's discourse is counter-hegemonic as it represents and introduces a different set of ideas, values, and most importantly, a different Arab identity. Similarly, the US public diplomacy initiative represented in Al-Hurra is an example of a hegemonic discourse that represents the most powerful state in global politics, and consequently introduces another presentation of Arab identity that serves its political interests.

\section{Theoretical Framework: Media, Globalization and Hegemony}

Gramsci developed the term "hegemony" to describe how one class dominates the others by a combination of political and ideological means. In his view, media disseminates the ideas that maintain the status quo and keeps the elite's grip over power policy (Abercombie, 1996, p. 161). Robert Cox introduced this 
idea to the field of international relations by arguing that hegemony is important in preserving the stability of world order. In his view, great world powers have succeeded in establishing a global order favorable to their interests by promoting a set of hegemonic ideas in parallel with their coercive power (Callinicos, 2002, p. 275; Hobden \& Jones, 1997, pp. 209-211).

Not only is hegemony about ideas, but it is also about the representation of identities. As Butler (1999) and Mann (1999) argued, hegemonic discourse is essential to national identities as it contains references to, and social implications for, race, class and gender. This way, hegemonic discourse creates a national identity that is different or opposed to an international "other" (McPhail, 1991, p.34). Media obviously plays an essential role in developing and maintaining hegemony.

However, with advancements in communication technologies, this hegemonic role of the media was questioned: how far do media represent the dominant group? Price Monroe's (2002) idea of "market of loyalties" shows how media is used to maintain the distribution of power by promoting a set of political views, cultural ideas and slogans that maintain the existing power structure. New developments in media sphere, according to Monroe, challenges this arrangement. Governments can consequently respond either by redefining the power structure and accommodating new entrants or by taking effective steps to raise the barriers of entry (Monroe, 2002, p. 33).

Global media sphere has lifted the barriers of entry as it encouraged the creation of new national and regional media (Figenschou, 2014, p. 5). This was particularly the case with the Arab sphere since the 1990s. The CNN coverage of the Gulf War introduced Arab governments to the power of satellites (Robinson, 2002) and confronted them with the ill performance of their national media; such a realization inspired the rise of Al-Jazeera which, subsequently, challenged Western hegemony over news production (Seib, 2008).

In this way, satellite media have provided some opportunities for the disadvantaged to express themselves, define their interests, represent their identity and challenge the hegemonic discourse of the more powerful states (Volkmer, 1999, p. 48). When counterhegemonic discourse becomes much stronger, hegemony fails (Lull, 2000, p. 71).

\section{Arab Identity}

Contextualizing Al-Jazeera's identity discourse is important to understand its description as a pan-Arab media. It also serves as a preliminary step in comparing it to Al-Hurra. Defining identity was always a contesting issue among scholars. The traditional view perceives identity as a given based on the primordial factors. According to this perception, identity refers to a group of people sharing a common fixed culture, history, lan- guage and most importantly, a common ancestry. On its part, social constructivism perceives identities as modern developments and inventions. Instead of focusing on the "objective" characters of the identities, constructivists deal with the phenomenon as mainly psychological and cultural artifact-i.e., an imagined community (Anderson, 1991).

In his seminal work on the Transformation of the Public Sphere, Habermas (1989) defined public sphere as the domain of social life where public opinion is formed by discussing matters of general interest without the interference of the authorities. In this virtual space, people interact, exchange ideas and information, and discuss issues of general interests (McKee, 2004 , pp. 4-5). Media have been widely recognized as the modern manifestation of the bourgeoisie public sphere described by Habermas. This conception of the public and, consequently, media spheres is not far from the debate on identities. Traditionalists argue that people engage in the public sphere with a pre-given identity. In this case, media only reflect on the existing identity; if there is no existing collective identity, there would be no public sphere. In contrast, constructivists perceive the development of public sphere and collective identity as being constructed through the social, political and discursive practices. Building on this conception, media thus play an important role in the representation and formation of identities. In other words, the story of media spheres is conducive to the story of national identities.

Although primordial claims are difficult to prove, it is possible to show how Arabs developed some sense of belonging before calling it "Arab nationalism," i.e. before the political engineering of Arab identity. While many scholars disagree on dating the first appearance of Arab nationalism, most of them agree that Gamal Abdel Nasser's era represented the peak of "Arab nationalism". The issues debated and circulated in the Arab media sphere have influenced the definition of Arab identity. The following discussion explores how the issues debated and circulated in the Arab media sphere have influenced the definition of Arab identity.

\subsection{The Arab Media Sphere and Arab Identity}

Building on the previous discussion on the traditional versus constructivist views on identities, this study differentiates between Arabness/Arabism and Arab nationalism/Pan-Arabism. Arabism is a cultural expression of identity that refers to, and includes, many elements like language, history, religion and culture. As for Arab nationalism, it adds to these cultural traits a political aim: uniting Arabs in a one single state. "Solidarity vs. unity" distinguishes the two terms. While solidarity is the ultimate goal of Arabism, Arab nationalism survives on the dream of unity (Dawisha, 2005, p. 8).

According to Ernest Dawn (1973), Arab nationalism 
started as an opposition movement in the Ottoman Empire without necessarily separatist tendencies. At that time, Arab admired Western scientific progress, but loathed Western accusations of Islam as the reason for Muslims' underdevelopment. This was an Arab cultural revival that stressed the role of the Arabic language and the status of Arabs in the heritage of Islam. This trend was accompanied by the development of private print press by the new large-landowners class and a newly educated class composed largely of local Christians. Private press was generally tolerated as long as there was no direct criticism of the Ottoman government (Ayalon, 1995, pp. 28-29).

Nascent Arab national consciousness was, thus, mainly based on language and culture to distinguish itself vis-à-vis the Ottomans. This could be called "Arabness/Arabism." At that time, the majority was still hoping for special status for Arabs within the Ottoman Empire under the umbrella of Islam (Khalidi, 1981). It was only after the secular chauvinist trend of Young Turkish became clear that religion was employed. Independence was presented as a preliminary step to restore the golden days of Arabs and consequently, Islam. Turkish, in this way, became the Arabs "Other."

During World War I, Arabs fought with the allies against the Ottoman Empire. They asked for, and were promised, their independence. Post-war arrangements, however, wrote the first chapter in the tensioned history between Arabs and the West. Arabs were traumatized by what they considered as Western betrayal. This left deep imprints on the construction of Arab identity as independence became the primary concern of Arab nationalists who framed colonialism as the Arab's "other".

Under colonialism, media, represented in the press, played a vital role in developing the nationalist sentiments among Arabs. The interwar period was particularly a period of relatively greater autonomy for the press (Ayalon, 1995, pp. 75-124) that led to the expansion of the Arab public sphere. Writing about the distinctive characters of Arabs and the need for them to be united in one nation had flourished. Sati'al-Husari's writings reflected these ideas stressing the role of common history and language in Arab identity.

However, the one issue that sparked the Arab public sphere was that of Palestine and the danger of Jewish immigration. Arabs from their different loyalties and perspectives all agreed on the need to resist the demographic changes that were under way in Palestine at that time (Dawisha, 2005, p. 107). When Arabs were defeated in 1948, the Palestinian issue became a defining mark in Arab identity. As Tareq Ismael (1976, pp. 1213) described, the defeat was "traumatic to the Arab masses...that it fostered a transformation of Arab nationalism from the glories of the past to the failuresparticularly the failure in Palestine-of the present".

The post-independence phase stressed the role of the Arab state. Media became the state's main institu- tion in mobilizing popular support. The adopted topdown model of communication stressed state's unity as a predominant social value. Soon, the Egyptian President, Gamal Abdel Nasser, recognized the influential power of media on regional politics. This was the role played by the influential Egyptian radio station of Sawt Al- Arab (Voice of the Arab), that had sown the seeds of pan-Arab media. At that moment, the Arab's "Other" was clear: imperialism and its local collaborators (Dawisha, 2005, p. 285). The Palestinian issue has since become a key issue, if not the key issue, in shaping Arab identity and modelling Arabs' relationships with the West. Arabs themselves were classified into unionists and sovereigntists. The former promoted the idea of one Arab sovereign state where Arabs share oil wealth and receive equal treatment. The latter preferred solidarity and support for other fellow Arabs without necessarily compromising their sovereignty or sharing their wealth. In other words, while the former defined Arab identity in terms of Arab nationalism/PanArabism, the latter perceived it as "Arabness/Arabism".

The perception of unity was built upon a glorious history and subsequent suffering (Chalala, 1987); it was also a unity of language and hope. These were the main elements that were stressed in the first phase of Arabism and circulated in the Arab public sphere. Then, a political dimension was added to these cultural factors: Arabs were to be united into one nation. This was the phase of Arab nationalism and the objectification of Arab identity.

The shocking defeat in the 1967 war damaged Arabs' trust in their media for its fabricated news (James, 2006), and obliged Arab nationalists to lower their demands from Arab unity to Arab solidarity (Dawisha, 2005, pp. 243-246). Moreover, conservative Arab states regained control over their media sphere after Nasser's defeat. Saudi Arabia was one of the Arab countries that suffered the most from Nasser's propaganda. Therefore, following the 1967 war, the Saudis' ownership of regional newspapers increased to promote a regional outlook consistent with their policies. With the Lebanese civil war, an increasing number of Lebanese journalists and newspapers relocated outside the region. Lebanese professionalism allied with Saudi money to dominate Arab media sphere (Miles, 2005, p. 24). The defeat also exposed the failure of the secularoriented Arab nationalism (Kramer, 1993, pp. 171-206), and opened new venues for discussing allegiance to the ummah (Islamic community).

This short overview shows how certain issues have always played an important role in the formation of Arab identity: history (particularly colonialism and relations with the West), Arab unity (defining who is included or excluded and reflecting upon inter-Arab interactions), the Palestinian issue (although related to the history of colonialism, it became a defining character of its own), and religion (Islam). Arab identity rep- 
resentation in both Al-Hurra and Al-Jazeera will be analyzed against this background to see which factors are highlighted and those that are downplayed.

\section{Methodology}

This study mainly relies on critical discourse analysis (CDA), with occasional support from framing theory and content analysis, in analyzing the media messages of the two channels. According to CDA, discourse is an instrument of power, control and the social construction of reality. CDA is interested in how texts and speeches enact, reproduce and/or resist social power, dominance and inequality in the social and political contexts (Van Dijik, 2003). It is also interested in the study of identity construction and changes of identities at both the national and transnational levels (Wodak, 2002 , p. 18). The relevance of CDA to this study emanates from the assumption that discourse shapes as well as expresses identities (Larson \& Pepper, 2003), and its interest in the social processes and structures surrounding the production of a text which, consequently, influences how individuals or groups create meaning in their interaction with the text (Wodak, 2002, p. 12). This means that it pays attention to certain questions such as, who is communicating, with whom and why. Moreover, it is concerned with the kind of society and situation that the communication targets and through what medium (Bell \& Garret, 1998, p. 3).

The study is particularly interested in the text itself (the discourse of the two channels) as well as its the socio-cultural (structural) contexts. The analysis, then, takes part on two levels: the macro level: analyzing the context of the discourse and the structural context of the media messages, and the micro-level: the language of the discourse, who is participating, and identifying who is "Us" vs. "Them". In applying this tool, this study analyzes the context in which both channels started broadcasting and how this affected their future reputation and the reception of their messages. Secondly, the study examines the use of language in the discourse of both channels to see how tactical this usage is and how it relates to the assumption of identity they represent. Thirdly, the structure of the discourse itself is analyzed to check its consistency and uncover the ideological assumptions, especially those related to the underlying perception of identity.

Framing also helps in discerning the underlying reasons for reporting the news in a certain way and in suggesting why certain pieces of news (or certain issues) are given more emphasis than others (Allen, O'Laughlin, Japerson, \& Sullivan, 1994, pp. 255-285). Framing analysis is closely connected and complementary to discourse analysis. Discussing the context in which the two channels appear and who were behind them, helps in understanding their respective frames.

This study analyses two talk shows from each chan- nel, in addition to the news bulletin during the Gaza 2008-2009 War. In analyzing talk shows, the study pays special attention to the introduction given by the presenter as it defines the limits of what will/will not be discussed and the way the event is framed. By controlling the premises of a discussion, the speaker can guide what their audience thinks about and influence the conclusions drawn (Bulter, 1999).

In choosing the shows, the study selected shows that are as similar as possible in format. From Al-Hurra, the study chose Sa'a Hura (Free Hour) which is a daily one-hour program that examines and discusses the news and stories of the day. The equivalent to this format in Al-Jazeera is Ma Wara' Al Khabar (What is behind the news). The second program is Al-Itijahat alArba'(The Four Directions) in Al-Hurra which is a roundtable discussion that provides analysis and comments on the main events of the previous week. The equivalent to this show in Al-Jazeera is Akthar Min Ra'y (More than One opinion).

As the overview on Arab identity revealed, the Palestinian issue occupies a special place in the formation of Arab identity. The Gaza War (2008-2009) was the first major event directly related to the Palestinian issue that took place after Al-Hurra went on air. It is, therefore, interesting to see how the two channels dealt with the event. The study relies on two sets of data: the episodes of the selected talk shows (25 episodes from Al-Jazeera and 26 episodes from Al-Hurra), and the nightly news bulletin in both Al-Jazeera (Hasad al-Yum: the day's harvest) and Al-Hurra ('al'almiyya: The Global). The data is analyzed over the period from December 27, 2008 to January 18, 2009. The first date refers to the start of the war and the second corresponds to Israel's unilateral ceasefire.

The study adopts a priori coding where the categories are already established before the analysis based on previous literatures and existing frameworks (Stemler, 2001). The study selects the categories that serve its overall purpose and match its methodology. The selected codes particularly correspond with discourse analysis and framing theory. The analysis derives codes from El Masry, El Shamy, Manning, Mills and Auter (2013), Figenschou (2014), and Dobering, Lobinger and Wetzstein (2010). The following variables and analytical categories were included in the overall analysis.

- Representation of guests in each channel (Palestinians, Israelis, Other).

- Representation of the Palestinian side (Fattah, Hamas, Other).

- Representation of the Palestinian viewpoint (Hamas, Fattah, Other).

- Information sources (Palestinian-Israeli)

- Type of views represented (Official, Specialists, popular). 
- Location of the first report (Palestine, Israel, Other).

- Dominant Frames represented (humanitarian, political...).

- Words used to describe Israeli and Palestinian actions.

- Description of Israeli and Palestinian casualties.

\section{The Story of Two Channels: Contextual and Conceptual Aspects}

Understanding the historical moment and the different institutional arrangements within which each channel started working is a preliminary step in making sense of their discourse. Al-Jazeera was part of Sheikh Hamad bin Khalifa Al-Thani (Emir of Qatar 1998-2013) progressive plan to introduce a distinctive ruling style. From the beginning, the channel was playing an indispensable role in Qatar's attempt to redefine itself (Booth, 2010). This is why its "perceived" credibility, independence (Figenschou, 2014, p. 27), and nonpartisan (el-Nawawy \& Iskander, 2002, p. 33; Miles, 2005, pp. 28-29) ${ }^{1}$ were prerequisites to fulfil this role. It explains why the Qatari government officially distanced itself from Al-Jazeera and resisted the different pressures to control its content. Al-Jazeera has also put an end to the Saudi-Lebanese hegemony over Arab media sphere (El Oifi, 2005, pp. 70-71), thus, changing the structure of media power relations in the region.

Al-Jazeera quickly won a reputation as revolutionary and provocative by promoting debates about political, religious and social topics that used to be taboo in Arab societies. The channel has successfully managed to project its identity beyond its funding country and its regional boundaries (Lahneman, 2005). Capitalizing on the Palestinian issue gave the channel its pan-Arab credentials and won it unprecedented regional fame (Miles, 2005, p. 73). Its coverage stirred up Arab public opinion against the US bias towards Israel (Bessaiso, 2005, p. 160).

The US war on Afghanistan ushered the end of Western media monopoly (Bessaiso, 2005, p. 165) as Al-Jazzera was the only channel allowed to work there. It was an example of information flow reversal: from the South/Orient to the North/Occident. Al-Jazeera presented an alternative news coverage highlighting civilian casualties caused by American air strikes. Deprived of its "on air supremacy", the US attempted to influence the editorial independence of Al-Jazeera (El-Nawaey \& Iskander, 2003, p. 176). The attempt itself ruined the US image as a supporter of media freedom and raised doubts regarding its discourse on democracy.

\footnotetext{
1 The so-called Arab Spring has exposed the built in contradictions of Al-Jazeera and challenged its "perceived" independence due to the discernible stance taken by Qatar towards certain regional allies, and its impact on Al-Jazeera's coverage.
}

Against this background, the Iraqi war (2003) took place. For the second time, the US found itself losing the propaganda war. While pan-Arab media concentrated on the humanitarian sufferings and civilian loss due to "occupation", their American counterparts portrayed the war as an act of popular liberation. With the increasing violence in Iraq, the US became furious with Arab media, particularly Al-Jazeera, for portraying these acts as "resistance" (Lynch, 2006, pp. 5-6). Convinced by the importance of the "war of ideas," the US decided to counter its perception as "arrogant, impatient and unwilling to listen" by the Arab public opinion (McDonald, 2000, p. 69). Defining the problem as one of image and information deficit, the US approached the region assuming that American policies needed better marketing to win Arabs' hearts and minds.

Al-Hurra has, thus, arrived at an inappropriate moment where hostility to American policies in the region was at its highest because of its war on terrorism, a war that was widely perceived as a war against Islam. Language use has fed these pre-held conceptions. For example, the common greeting in Arab media is the Islamic one of "al-sallamu 'alaykum"' (peace be upon you). Al-Hurra's presenters avoid this greeting and use 'welcome back' instead. The greeting itself, as Baylouny correctly noted, confirms perceptions that the US is against the region's religion (Baylouny, 2005, p. 21). Moreover, Al-Hurra was a late comer to the Arab media sphere and encountered a very competitive environment. Nevertheless, Al-Hurra's founding perceptions assumed that Arab media sphere resembled the former Soviet Union space during the Cold War. ${ }^{2}$ Such a mistaken conception made Al-Hurra seem "redundant in content, and preachy in tone" (Kraidy, 2006, p. 3).

Not only was Al-Hurra working in a highly competitive media environment, but it was also influenced by institutional constraints that were not that obvious in Al-Jazeera (Collins, 2008). The channel was required to meet the expectation of Congress, American conservative press and people in Washington D.C as well as Ar$\mathrm{ab}$ audiences. Such an expectation is unattainable giving the different perspectives of these parties. In addition, Al-Hurra's message lacked credibility. While its message was about freedom and democracy, the US

\footnotetext{
2 In his testimony in the House of Representative, Mouafac Harb claimed that:

"Alhurra introduces to the region ideas of truth and freedom and democracy never before discussed. Alhurra brings to the vast region of the Middle East unprecedented town hall meetings, talk shows, and debates....We have to continue to foster these conversations, these debates, until they become a part of the lives of the people of this region, until they become part of life in the Islamic world." Statement of Mr. Mouafac Harb. Broadcasting Board of Governors and AlHurra Television. Hearing before the subcommittee on oversight and investigations of the committee on international relations, House of Representatives. First session, 10th November 2005.
} 
was occupying Iraq and allying with authoritarian regimes. The public diplomacy campaign was thus tainted as an act of hypocrisy (Napoli \& Fejeran, 2004).

\section{Discussion: Mapping the 2009 Gaza War Coverage on Both Channels: Content-Related Aspects}

Before delving into the details of the coverage of the two channels and its relationship to Arab identity representation, it is important to highlight general observations on the way each of them covered the war.

In general, Al-Hurra was more representative of the Israeli viewpoint. For example, in news bulletins, Israeli guests represented $32 \%$ of the total guests, while Pal- estinian guests represented $28 \%$ (Table 1). Although the number of Palestinian guests (24\%) in Al-Hurra's daily discussion show "Free Hour" exceeded that of the Israeli guests (10\%), the American guests (30\%) were staunch defenders of the Israeli view (Figure 2). This raises the percentage of the Israeli point of view to $40 \%$. Moreover, the news excerpts from Israeli sources were $62 \%$, while those from their Palestinian counterparts were $37 \%$. News reporting started from the Israeli side $57 \%$ of the time, while reporting from Gaza started only $42 \%$ of the time, despite the expected interest of Arab viewers to hear and see first from the Palestinian side.

Table 1. The number of guests on each channel's news bulletin.

\begin{tabular}{lll}
\hline Criteria & Al-Jazeera & Al-Hurra \\
\hline No. of Palestinian Guests & 29 & 16 \\
No. of Israeli Guests & 6 & 18 \\
Other & 98 & 22 \\
Total & 133 & 56 \\
\hline
\end{tabular}

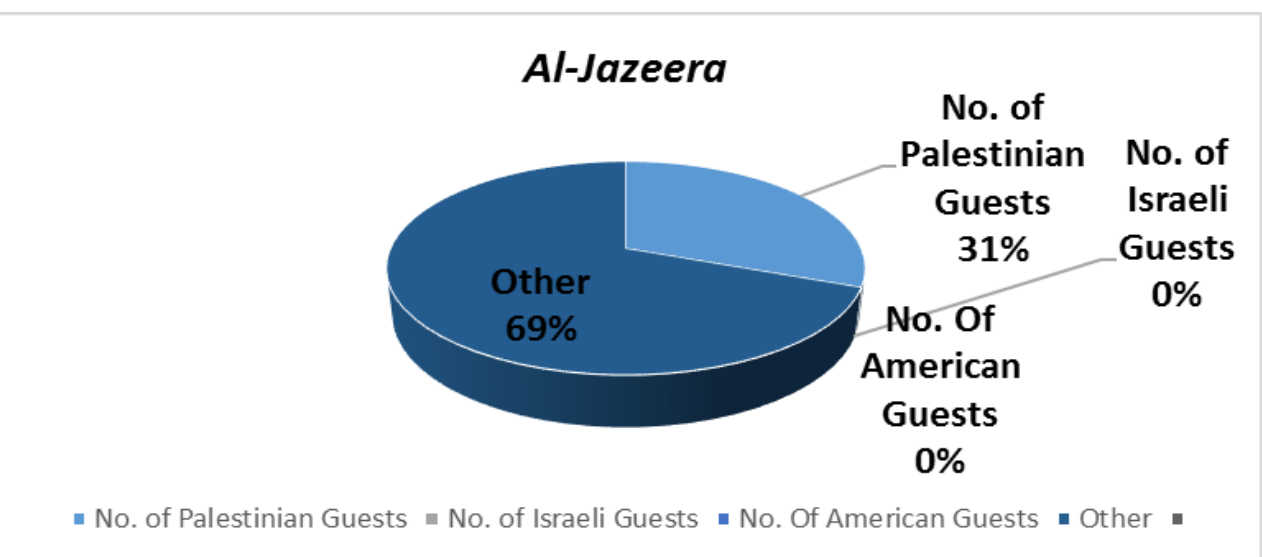

Figure 1. Representation of guests in Al-Jazeera's talk show.

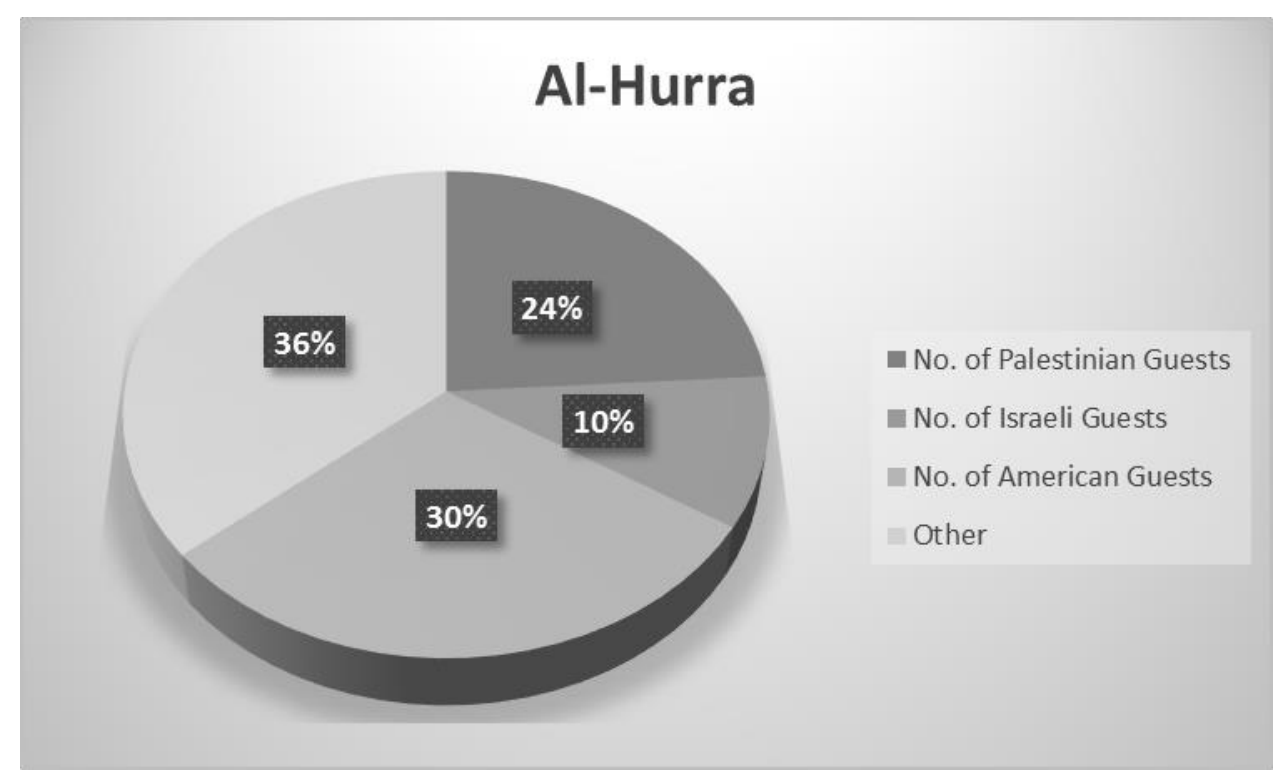

Figure 2. Representation of guests on Al-Hurra's talk shows. 
Al-Hurra's representation of the Palestinian voice favoured one party; Fattah (Figure 3 and Table 2). Palestinians belonging to Fattah represented $28 \%$ of the Palestinian voice in "Free Hour", while Hamas was not represented. Non-Palestinian guests represented $68 \%$ of the total guests where $40 \%$ of them were against Hamas and blamed the movement for the war. The same pattern appears in the news bulletins where Fattah's guests constituted $75 \%$ of the Palestinian voices, while Hamas was absent and other Palestinian voices only represented $35 \%$. Al-Hurra focused more on the official viewpoint of different parties. Official voices represented $46 \%$ of the guests on the talk shows, while popular voices were only represented by $4 \%$. The same applies to news bulletins where official voices represented $54 \%$ of the guests while popular voices represented 16\%. (Figures 6 and 7).

Table 2. Hamas' point of view vs. Fattah in discussion shows

\begin{tabular}{|c|c|c|c|c|}
\hline Guests & Al-Jazeera & $\%$ & Al-Hurra & $\%$ \\
\hline Hamas & 1 & 3 & 0 & 0 \\
\hline Fattah & 0 & 0 & 14 & 28 \\
\hline Non-Affiliated Palestinians & 10 & 26 & 2 & 4 \\
\hline 1-Supporting Hamas & 10 & 26 & 1 & 2 \\
\hline 2-Against Hamas & 0 & 0 & 0 & 0 \\
\hline 3- Neutral & 0 & 0 & 1 & 2 \\
\hline Other & 28 & 72 & 34 & 68 \\
\hline 1-Supporting Hamas & 16 & 41 & 1 & 2 \\
\hline 2-Against Hamas & 4 & 10 & 20 & 40 \\
\hline 3- Neutral & 8 & 21 & 13 & 26 \\
\hline Total & 39 & 100 & 50 & 100 \\
\hline
\end{tabular}

\section{THE PALESTINIAN VOICE IN NEWS BULLETIN}

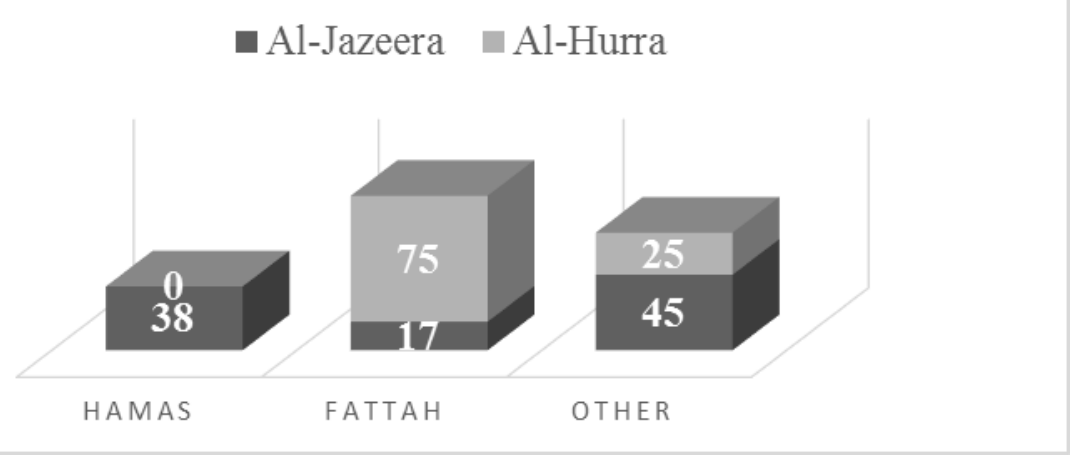

Figure 3. The Palestinian voice in news bulletins

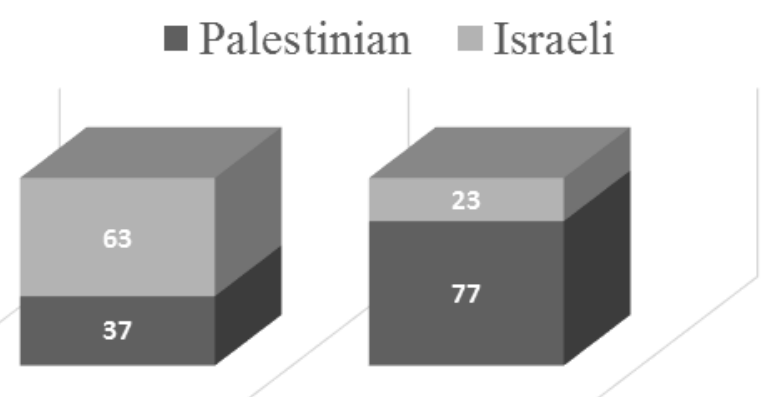

\section{AL-HURRA AL-JAZEERA}

Figure 4. Percentage of excerpts from the Palestinian vis-a-vis the Israeli sources in the news. ${ }^{3}$

\footnotetext{
${ }^{3}$ Any piece of news proceeded by: said, announced, confessed, recognized, broadcasted...etc.
} 


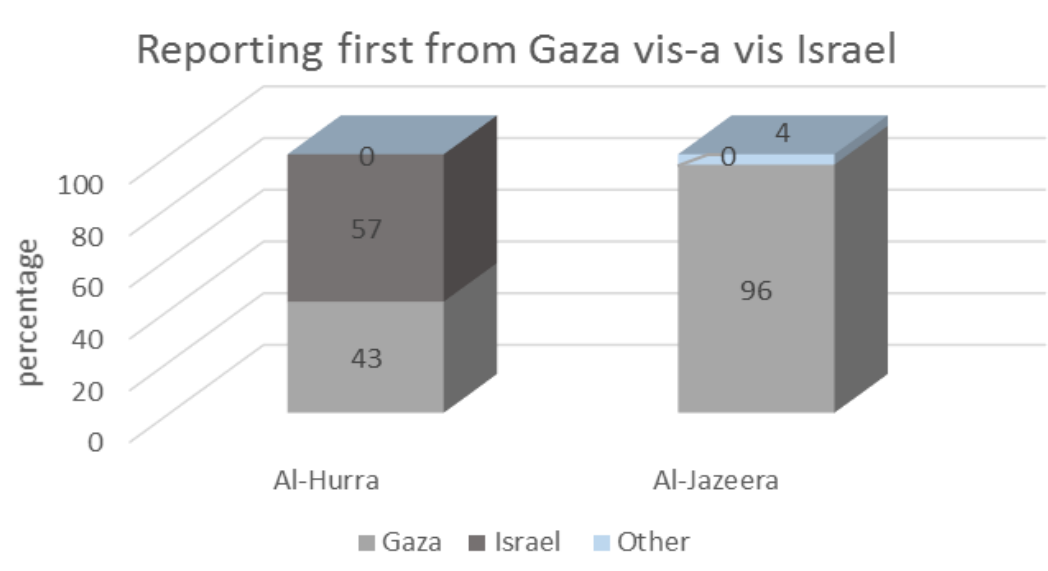

Figure 5. The reporter who spoke first in the news.

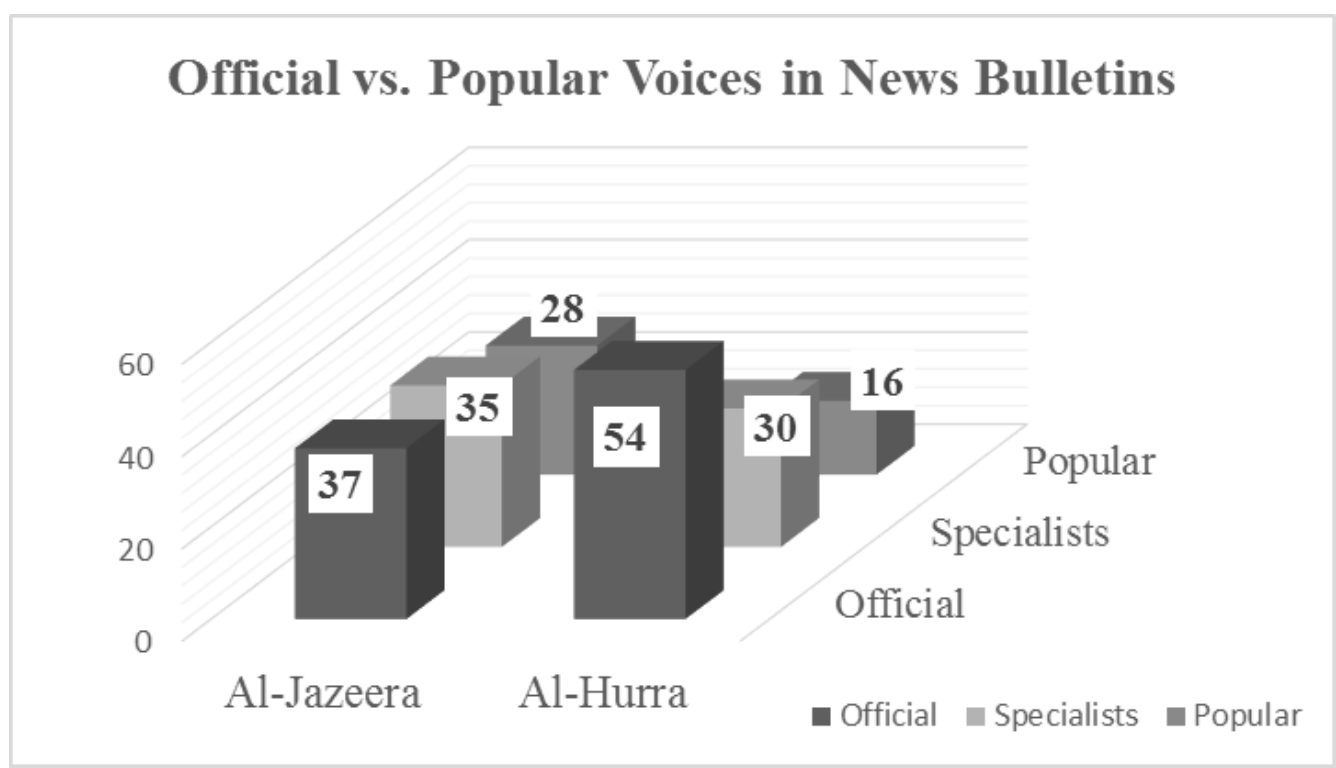

Figure 6. The popular vs. the official voices in news bulletins' guests. ${ }^{4}$

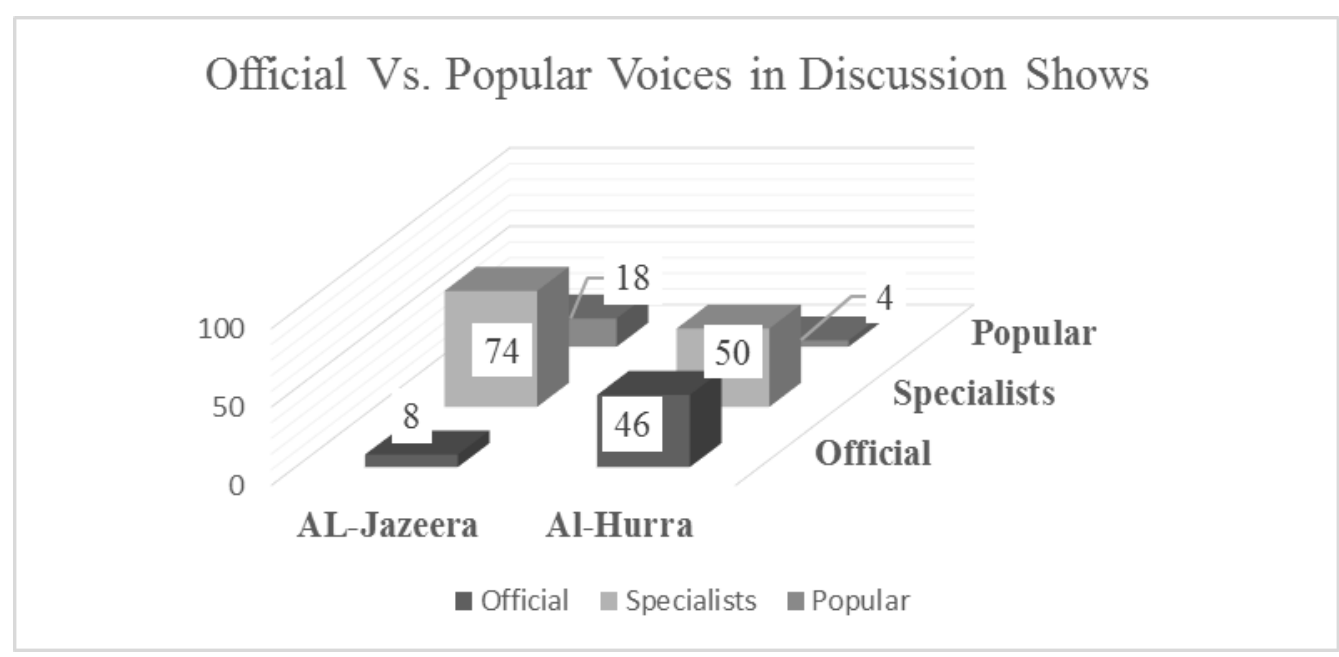

Figure 7. The official vs. popular voices in discussion shows' guests.

\footnotetext{
${ }^{4}$ The study considers the representative of Hamas and Fattah as part of the official voice, while the rest of the Palestinian groups and parties as popular voices. The same applies to the representatives of the UN. As for doctors and specialists in international law, they are counted as part of the specialists' voice.
} 
Al-Jazeera's coverage reflected different trends. Israeli guests represented almost $5 \%$ of the guests in the news bulletins, while the Palestinians were $22 \%$. This pattern was more visible in the channel's daily discussion show of 'what is behind the news' where Palestinian guests constituted $31 \%$ of all the guests, while the Israelis were absent (Table 1 and Figure 1). While excerpts from the Israeli sources during the news bulletins were used $23 \%$ of the time, those from the Palestinian side represented $76 \%$ (Figure 5). Unlike Al-Hurra, news reports in Al-Jazeera used to begin with the Palestinian side in Gaza (Figure 5). Interest in the Palestinian side was also reflected in the number of reporters working in Gaza and the percentage of times (95\%) the news reporting started from it (Figure 4). Al-Jazeera's coverage was biased towards the party involved in the fight: Hamas. Therefore, the percentage of Palestinians in the news bulletins belonging to Fattah was $17 \%$, while that representing Hamas was $38 \%$. For the discussion shows, $3 \%$ belonged to Hamas in contrast to $0 \%$ for those who belonged to Fattah. However, voices defending Hamas and representing its viewpoint, from either non-affiliated Palestinians or other guests, represented $67 \%$ (See Figures 3 and 4)

In contrast to Al-Hurra, Al-Jazeera gave more airtime to popular voices. The number of official voices in Al-Jazeera was 49 while the number of the popular voices was only 37 . For Al-Hurra, the difference was 30 vs. 9 in favor of the official voices. The fact that the specialists' voices on Al-Jazeera were non-official ones, raises the percentage of the non-official voices to $63 \%$. Regarding the discussion shows, the official voice was the minority (8\%) vis-a-vis that of the people (18\%) and of the specialists (74\%) (Figures 6 and 7). This makes AlJazeera more representative of the popular voice and promotes its image more as "the people's channel".

Interest in listening to the public reflects how the public is generally perceived. The traditional perception of Arab citizen viewers is that they are "naive and overly critical, uncivilized and chaotic, unable to demonstrate peacefully" (Chaieb, 2007, p. 71). As Abdelmoula (2015, pp. 106-107) argued, when Al-Jazeera gives more airtime to Arab viewers, this reflects a conviction that the public deserve listening to and identifying their needs. This perception represents, in his view, an "enlightening" role by Al-Jazeera for helping Arabs acquiring the courage to express their views free of fear without always waiting for guidance. By contrast, when Al-Hurra listens less to Arab viewers it endorses their negative image.

The war coverage of the two channels can be mapped by comparing the following aspects: targets (Who/what was the target?), results (Who succeeded?), and the repercussions of the war. Answering these questions will reflect on the representation of the region's identity in both channels, i.e. who is the "other"? What elements are stressed in identity construction?

\subsection{Target}

Al-Hurra's coverage conveyed the message that the attacks were mainly targeting Hamas and its locations in Gaza. The channel extensively repeated the Israeli assertion that "all the targeted locations belong to Hamas" (Al-'Alamiyya, December 27, 2008). Graphic images mainly showed the destruction of buildings but filtered out civilian casualties and sufferings. AlJazeera's coverage in contrast conveyed the message that the attacks, or the aggression as was labelled, targeted everyone in Gaza. The two channels employed language differently to present their respective coverage messages. Al-Hurra, for example, described people who lost their lives by Israeli strikes as being "killed", while Al-Jazeera called them martyrs. Furthermore, AlHurra labelled the strikes as a bombardment (qasf), not as a war or aggression, or even attacks as did AlJazeera. Israeli military actions were also described as "operations", not war as in Al-Jazeera to belittle the wide scale and strength of the action.

Al-Jazeera developed a promo for the attacks showing the scattered corpses of Palestinian police in Gaza while one of the wounded was raising his fingers enunciating Islam's two professions. ${ }^{5}$ The promo itself was enough to entice feelings of anger and sympathy as well as recalling the religious aspect. The promo's title was "Gaza under Fire" and "War on Gaza" to indicate that it was a war on all of Gaza, not only on a certain group. Al-Hurra, for its part, and after a few days from the beginning of the war, developed its promo in which it showed an unidentified artillery truck and titled it as "War in Gaza." Using the proposition "in" indicates that there were equal parties involved in the conflict without blaming one particular party for waging the war.

Reporting from the West Bank was also different between Al-Hurra and Al-Jazeera. For example, on December 28, 2009, Al-Jazeera's news mentioned, "a Palestinian youth was killed after the 'occupation' forces shot him in Ramallah" (Hasad Al-Yum, December 28, 2008). This piece of news came immediately after reporting from Gaza in a way indicating that the occupation is the same and it kills "here" in Gaza and "there" in the West Bank. Al-Hurra reported the same story differently. First, the story came after the news interval contextualizing it among the different reactions to the event. The news read as "a Palestinian youth was killed after clashes with the Israeli forces" (Al-'Alamiyya, December 28, 2008). Noticeable here is how Al-Hurra used "Israeli" instead of "occupation" forces. Moreover, Al-Hurra mentioned that he was "killed after clashes with the Israeli forces" (Al-'Alamiyya, December 27,2008$)$. This way, the channel did not directly

\footnotetext{
${ }^{5}$ This is to profess that there is no God but God and that Muhammad is the messenger of God. ašhadu 'an laa ilāha illa (A)llāh, wa 'ašhadu 'anna Muhammada(n) rasūlo (A)llāh.
} 
blame the Israeli forces for his death by portraying the incident as a result of mutual violence.

In a manner of speaking, Al-Hurra's coverage tried to exonerate Israel from accusations that it was intentionally targeting civilians while Al-Jazeera's was explicitly stressing the deliberation. Al-Jazeera made every effort to set the conflict in a broader context, one that recalled painful episodes from the region's post-World War II history. Al-Hurra, on the other hand, tried to present the Gaza conflict as either a unique incident or one that was only representative of Israel-Hamas antagonisms.

\subsubsection{Success}

The two channels introduced different definitions of war failure or success. For Al-Hurra, it was a matter of a balance of power, while Al-Jazeera considered it as a war of wills and defended the right to resist the occupation. According to al-Hurra the operation resulted in a difficult humanitarian situation that needed extensive diplomatic efforts to stop the fighting, not to put an end to occupation as al-Jazeera was conveying. AlHurra portrayed Israel as the war's winner. Reporters repeatedly described the "operation" as a success for Israel, which "feels comfortable and victorious" (Al'Alamiyya, December 30, 2008). Al-Jazeera on the contrary, was stressing from the beginning that Israel was losing the war. The high death toll among Palestinians was itself, according to Al-Jazeera's coverage, a sign that Israel failed to achieve its goals and, therefore, decided to revenge. In other words, while Al-Hurra stressed rational material calculations in defining success, Al-Jazeera adopted abstract and moral determinants that corresponds more with the cultural beliefs in the region.

\subsubsection{Repercussions of the War}

Al-Hurra was mainly interested in the future of the peace process and the impact of the war on the region. The US role under the then new Obama administration was linked to this discussion. As for the impact of the war, it mainly referred to the future of the regimes, the future of the Palestinian authority vis-à-vis Hamas, the establishment of Israel's power of deterrence and the influence of Islamic extremism.

Al-Hurra's coverage portrayed the Palestinian issue as the major source of Arab-Arab dispute. For example, the presenter of "Free Hour" - Hussein Jardi-asked "is it possible for the Gaza war to become an Arab- Arab conflict?" (Free Hour, January 14, 2008). Whether the war would strengthen or weaken Hamas was a big issue on Al-Hurra. The way the discussion progressed in most episodes gave the impression that it was better if Hamas lost, implying that Israel has to take the time to finish its job. Hamas, in view of most "Free Hour" guests was not an option to be considered. Even if it was re-elected, one of the guests expressed, dealing with it was not possible.

Al-Hurra introduced the Palestinian-Palestinian split as irreconcilable the same time it was discussing the possibility of resuming the peace process between the Palestinians and Israelis. There were questions about the possibility that the war "would change the face of the Palestinian-Israeli conflict in particular and the situation in the region in general, and whether the Israeli army would be able to put an end to Hamas" (Four Directions, January 2, 2009). Putting these questions within Al-Hurra's broader discussion framework imply that if Israel manages to terminate Hamas, there would be new arrangements that could change the face of the Palestinian-Israeli conflict. Hamas' failure was, thus, in the best interest of the Palestinian authority as well as for the future of the peace process. ${ }^{6}$

Al-Jazeera's discussion on war repercussions was different. Its main interest was how to reframe Palestinian unity and Arab positions within a broader strategy of resistance. According to many of the guests, as well as the comments of the presenters, Palestinians should abandon the hopeless path of negotiation. According to Al-Jazeera's extensive coverage, Arabs have to reconsider the choice of resistance and support the Palestinian armed groups. ${ }^{7}$ In contrast to Al-Hurra, AlJazeera doubted the possibility of reaching any settlement to the conflict without, effectively, engaging $\mathrm{Ha}$ mas. Moreover, the Palestinian issue, according to AlJazeera's coverage, was not a source of Arab divisions. On the contrary, the official Arab-Arab split is responsible for blocking the Palestinian unity talk and deepening the Palestinian-Palestinian rift. Therefore, there was a necessity to overcome Arab divisions and take a united stance against the aggression on Gaza.

\subsection{Regional Identity Representation}

Al-Hurra's war coverage conveyed the message that the region was suffering from an identity crisis, as divisions were the focal point. This even applied to the Palestinians where Hamas-Fattah split received much focus in comparison to acts of solidarity spread in the Palestinian street. The Palestinian split was also newsworthy compared to the clashes with the Israeli army

6 This was the hub of the discussion in Free Hour in several episodes: January $2 \mathrm{nd}$, January 5th, January 6th, January 11th, January 12 th and January 13 th.

7 In the episode of December 27, 2008, the spokesman of Hamas in Beirut, Osama Hamdan, said that Israel wants to break the will of the resistance. The presenter interrupted him by saying we do not disagree over specifying what Israel wants. Al-Mawqif al-Arabi min al-'Udwan al-Israili 'Ala Gaza [The Arab Position Towards the Israeli Aggression on Gaza]. Muhammad Krishan. What is Behind the News. Al-Jazeera. Qatar, Doha. December 27, 2008. 
in the West Bank. Al-Hurra never reported the acts of solidarity and demonstrations in the West Bank and the calls for unity. In this way, the Palestinian "other" was ambiguous: is it Hamas or Fattah? Meanwhile, "occupation" was neutralized. This "assumed" identity crisis led to ignoring Arab street's expression of unity and solidarity. Adding to the identity crisis is the downplayed role of religion in Al-Hurra's coverage. For example, the channel never mentioned the position of the Organization of Islamic Conference or the opinion of famous religious figures.

On its part, Al-Jazeera's coverage reflected a region that suffers from a political rather than an identity crisis. Divisions, according to Al-Jazeera, were mainly political in nature as solidarity and unity prevail on the popular level. Arab and Islamic solidarity in this view was a dominant feature of Arab Street. Political divisions themselves were portrayed as a conspiracy facilitated by the collaboration of the region's leaders. Classifications like "moderate" and "extremist" Arab states were refused by Al-Jazeera because they were imposed by the US and only worked in Israel's interest.

Arabs' "other," according to Al-Jazeera, was well defined. It was Israel that destabilizes the region, works on splitting it and kills innocents. News reported from Gaza and the West Bank was framed in a way that clearly identified the Palestinian, as well as Arabs', "other". It was Israel, not Hamas or Fattah, that was harming the Palestinian people. The occupation was the reason for their misery and split. The channel's coverage accused Israel of trying to embarrass other Arabs by portraying them as accomplices in the aggression. Israel is blamed for all the wrongdoings in the region not Iran or Syria as Al-Hurra was conveying.

Al-Jazeera's coverage presented an idealized notion of Arab identity; a monolithic identity founded upon authentic elements that revolve around religion (Islam), language and history. Religion, according to its coverage, was the glue that sticks Arabs together. Activities by religious figures received ample coverage. The channel also used to host religious figures from all over the Islamic world to discuss the religious duties of Muslims in the face of the crisis. Even the language used had religious connotations. News presenters and reporters, for example, frequently repeated expressions like "nusra" (religious solidarity).

History was another element that distinguished the coverage of the two channels. Al-Hurra focused on the present and future, rather than the past. This was clear, for example, in tackling the issue of democracy and peace between Arabs and the Israelis. The channel was silent on US support for Israeli policies over the years, but President Obama's position with regard to the issue of settlement was a focus point. This focus on the present and future makes the region's identity elastic as it is needed to promote the interests of the more powerful. This also makes the people in the re- gion more amenable to accept the hegemonic ideas that serve these interests.

History in Al-Jazeera's coverage, on the contrary, was always alive. The idea of resistance itself is highly representative of Arab history. Resistance has always been a main element in Arab's identity that appears whenever Arabs encounter colonial or imperial threats to their identity. The Palestinian issue exemplifies the high relevance of history. Arab rights, as perceived in Al-Jazeera, are rooted in history, therefore, none of these rights should be surrendered. History is thus an indispensable component of the region's identity.

As for language, Al-Jazeera's identity construction relies also on the use of standard Arabic. This reflects how the channel's executives perceive the Arab public as one "rather than a multitude of publics dispersed in twenty-two separate countries" (Abdelmoula, 2015, p. 116). Such a unifying factor is absent in Al-Hurra where different dialects are heard, particularly the Lebanese one in the beginning. Moreover, Al-Jazeera's anchors, reporters and journalists tend to use the rhetorical power of Arabic to affect emotions in a way that influences the Arab public's interpretation of events.

Because identity representation has to resonate with the people, media strategies employed by AlJazeera have been so far more successful than those of Al-Hurra. The former has the reputation as "the people's channel", while the other seems to be out of touch with its audience. As Shibley Telhami (2003) argues:

"Popular Arabic outlets succeeded because they reflected the hearts and minds of the region on core issues, not because they shaped them....[W]hile there are multiple reasons audiences view a particular station for news, the most critical factor is the extent to which a station reflects their views on issues that matter most to them and to their identity. When a station fails to do this, viewers look for alternatives." 8

\section{Conclusions}

The growth of transnational satellite television has challenged Western hegemony over news production. This has great repercussions on the United States and its actions/policies and threaten the effectiveness of its soft power. Arabs and Muslims increased access to information of their production had influenced the way they receive media messages from an outsider. AlJazeera made it difficult for the US to sell its image and

\footnotetext{
${ }^{8}$ We can extend the argument by comparing Al-Jazeera's share of popularity during and after the so-called Arab Spring revolutions. The change or fluctuation in its popularity may finds explanation in its representation or challenge of deep rooted ideas, perceptions and identities of its audiences.
} 
empowered an oppositional discourse that calls for authenticity and independence (Lynch, 2006, p. 25). The presence of Al-Hurra is representative of the challenges that the US policies are facing in the Arab world because of the influential role of the media. It shows how effective Al-Jazeera is to the extent that, as Ann Marie Baylony argued, it pushed the US to "legitimize itself, to defend itself against counter- [hegemonic] claims" (Baylouny, 2005).

The 2008-2009 Gaza War coverage has shown how Al-Jazeera stressed history, religion and Arabism as the defining elements of the region's identity. These are deeply rooted popular perceptions of Arab identity. AlHurra omitted regional history, belittled or ignored the role of religion and focused on regional political divisions. It promoted the image of a region that should get over its past and look forward to the future that marginalizes religion and history.

As this analysis shows, there are three factors that influence the level of success of the two channels. These factors are related to the three Cs (3Cs): context, conception and content. The construction of identity lies at the heart of the intersection between these factors. For a message of public diplomacy to find its way to its targeted audience, a certain kind of harmonic interaction needs to exist between these three components. Any inconsistency among these elements leads to the failure and/or fall of the public diplomacy of the media. This is a preliminary step towards a model for evaluating the public diplomacy of the media. Further examination of these factors in the context of the socalled Arab Spring is still needed to better understand the rise and fall of popularity of the two channels.

\section{Acknowledgments}

The author would like to thank Prof. Amilcar Barreto for his invaluable support and insights in investigating this topic. Special thanks are due to Dr. Linda Lebile for her meticulous revision of the paper in a very short time. The author also extends her gratitude to the anonymous reviewers for their valuable comments and suggestions.

\section{Conflict of Interests}

The author declares no conflict of interests.

\section{References}

Abdelmoula, E. (2015). Al Jazeera and democratization: The rise of the arab public sphere. New York: Routledge

Abercombie, N. (1996). Television and society. Cambridge: Polity Press.

Al-'Alamiyya. (December 27, 2008). Al-Hurra.

Al-'Alamiyya. (December 28, 2008). Al-Hurra.
Al-'Alamiyya. (December 30, 2008). Al-Hurra.

Allen, B., O'Loughlin, O., Japerson, A., \& Sullivan, J. (1994). The media and the gulf war: Framing, priming and the spiral of silence. Polity, 27(2), 255-285.

Anderson, B. (1991). Imagined communities: Reflections on the origin and spread of nationalism. London:Verso.

Ayalon, A. (1995). The press in the arab middle east: $A$ history. Oxford: Oxford University Pres

Baylouny, A.M. (2005). Al-manar and alhurra: competing satellite stations and ideologies. CSRC Discussion Paper, 5/49, 1-23.

Bell, A., \& Garret, P. (1998). Approaches to media discourse. Malden: Blackwell Publishers.

Bessaiso, E. (2005). Al-Jazeera and the war in Afghanistan: A delivery system or a mouthpiece? In M. Zayani (Ed.), The Al-Jazeera phenomenon: Critical perspectives on new arab media (pp. 153-170). London: Pluto Press.

Booth, R. (2010, December 5). WikiLeaks cables claim AlJazeera changed coverage to suit Qatari foregin policy. The Guardian. Retrieved from http://www.the guardian.com/world/2010/dec/05/wikileaks-cablesal-jazeera-qatari-foregin-policy

Butler, J. (1999). Gender trouble: Feminism and the subversion of identity. London: Routledge.

Callinicos, A. (2002). Marxism and global governance. In D. Held \& A. McGrew (Eds.), Governing globalization: Power, authority and global governance (pp. 249266). Cambridge: Polity Press.

Chaieb, L. (2007). The age of the masses. In E. Abdelmoula (Ed.), The Al-Jazeera decade:1996-2006. Jannusan, Bahrain: Al Waraqoon.

Chalala, E. (1987). Arab nationalism: a bibliographic essay. In T. Farah (Ed). pan arabism and arab nationalism: the continuing debate. Boulder: Westview Press.

Cochrane, P. (2004). Is Al-Hurra doomed. World Press. Retrieved from http://www.worldpress.org/mid east/1872.cfm

Collins, K. (2008). Al-Hurra television focus group research project: Critique of editorial content in order to enhance news judgment and build journalistic excellence. Columbia, Missouri, and Washington,D.C: Missouri School of Journalism.

Dawisha, A. (2005). Arab nationalism in the twentieth century. Princeton: Princeton University Press.

Dawn, E. (1973). From Ottomanism to Arabism. Essays on the origins of Arab nationalism. Illinois: University of Illinois Press.

Dobernig, K., Lobinger, K., \& Wetzstein, I. (2010). Covering conflict: Differences in visual and verbal news coverage of the Gaza crisis 2009 in four weekly news media. Journal of Visual Literacy, 29(1), 88-105.

El Masry, M., El Shamy, A., Manning, P., Mills, A., \& Auter, P. (2013). Al-Jazeera and al-Arabiya: Framing of the Israel-Palestine conflict during war and calm periods. The International Communication Gazette, 
75(8), 750-768.

El-Nawawy, M., \& Iskandel, A. (2002). Al-Jazeera: How the free Arab news network scooped the world and changed the Middle East. Cambridge, MA: Westview.

El-Nawawy, M., \& Iskander, A. (2003). Al-Jazeera: The story of the network that is rattling governments and redefining modern journalism. Cambridge, MA: Westview Press.

El Oifi, M. (2005). Influence without power: Al-Jazeera and the Arab public sphere. In M. Zayani (Ed.), The Al-Jazeera phenomenon: Critical perspectives on new Arab media (pp. 66-79). London: Pluto Press.

Figenschou, T. U. (2014). Al-Jazeera and the global media landscape: The south is talking back. New York, NY: Routledge.

Habermas, J. (1989). The structural transformation of the public sphere: An inquiry into a category of bourgeois society. Cambridge, MA: MIT Press.

Hobden, S., \& Wyn Jones, R. (1997). Marxist theories of international relations. In J. Baylis \& S. Smith (Eds.), The globalization of world politics: An introduction to international relations (pp. 200-223). Oxford: Oxford University Press.

Hasad al-Yum. (December 28, 2008). Al-Jazeera.

Ismael, T. (1976). The arab left. Syracuse: Syracuse University Press.

James, L. (2006). Whose voice? Nasser, the Arabs, and "Sawt al-Arab" radio. TBS. Retrieved from http:// www.tbsjournal.com/James.html

Hussien Jardi. (January 14, 2009). Free hour. Al-Hurra.

Khalidi, R. (1981). The press as a source for modern Arab political history: "Abd al-Ghani al-“Uraisi and alMufid. Arab Studies Quarterly, 3(1).

Kraidy, M. (2006). Arab media and US policy: A public diplomacy reset. The Stanley Foundation. Retrieved from

http://www.stanelyfoundation.org/publications/pab /PAB08Kraidy.pdf

Kramer, M. (1993). Arab nationalism: mistaken identity. Deadalus. Retrieved from http://scholar.harvard. edu/files/martinkramer/files/arabnationalism.pdf?m $=1360039101$

Krishan, M. (December 27, 2008). Al-Mawqif al-Arabi min al-'Udwan al-Israili 'Ala Gaza [The Arab Position Towards the Israeli Aggression on Gaza]. Al-Jazeera.

Lahenman, W. (2005). Impact of diaspora communities on national and global politics. Center for International and Security Studies at Maryland. Retrieved from http://www.cissm.umd.edu/papers/files/lahne men_diaspora_report.pdf

Larson, G., \& Pepper, G. (2003). Strategies for managing multiple organizational identifications: A case of competing identities. Management Communication Quarterly, 16(4), 528-557.

Lull, J. (2000). Media, communication, culture: A global approach. New York: Columbia University Press.

Lynch, M. (2006). Voices of the new Arab public: Iraq, Al-
Jazeera, and the Middle East politics today. New York: Columbia University Press.

Mann, K. (1999). Internarrative identity. Lanham, MD: University Press of America.

Mansi, S. (January 2, 2009). The four directions. AlHurra.

McDonald, J. (2000). The track not taken personal reflections on state department intransigence and conflict resolution. Harvard International Review, 22(3), 6871.

McKee, Alan. (2004). The public sphere: An introduction. Cambridge: Cambridge University Press.

McPhail, M. L. (1991). Complicity: the theory of negative difference. In R. Jackson II (Ed.), African American communication and identities (pp. 29-37). Thousand Oaks, CA: Sage Publications.

Miles, H. (2005). Al-Jazeera: How Arab TV news challenged the world. London: Abacus.

Monroe, P. (2002). Media and sovereignty: The global information revolution and its challenges to state power. Cambridge: MIT Press.

Napoli, J., \& Fejeran, J. (2004). Of two minds: US public diplomacy and the Middle East. Global Media Journal, 3(5). Retrieved from http://www.globalmedia journal.com/open-access/of-two-minds-us-publicdiplomacy-and-the-middle-east.pdf

Robinson, P. (2002). The CNN effect: The myth of news, foreign policy and intervention. London: Routledge.

Seib, P. (2008). The Al-Jazeera effect: How the new global media are reshaping world politics. Washington, D.C.: Potomac Books.

Stemler, Steve (2001). An overview of content analysis. Practical Assessment, Research \& Evaluation, 7(17). Retrieved from http://PAREonline.net/getvn.asp?v= $7 \& n=17$

Telhami, S. (2008). Annual Arab public opinion poll. University of Maryland with Zogby International. Retrieved from http://www.sadat.umd.edu/

Telhami, S. (2009). Annual Arab public opinion survey. University of Maryland with Zogby International. Retrieved from http://www.brookings.edu/ /media/ events/2009/5/19-arab-opinion/2009_arab_public _opinion_poll.pdf

Telhami, S. (2011). Annual Arab public opinion survey. University of Maryland with Zogby International. Retrieved from http://www.sadat.umd.edu/

Telhami, S. (2013). Al-Jazeera: The most-feared news network. Brookings Institution. Retrieved from http://www.brookings.edu/research/articles/2013/0 6/15-al-jazeera-news-network-world-arab-eyestelhami

Van Dijik, T. (2003). Critical discourse analysis. In D. Schiffrin, D. Tannen, \& H. Hamilton (Eds.), The handbook of discourse analysis (pp. 352-371). Malden: Blackwell Publishing.

Volkmer, I. (1999). News in the global sphere: A study of CNN and its impact on global communications. Lu- 
ton, UK: University of Luton Press.

Wodak, R. (2002). Aspects of critical discourse analysis.
ZFAL, 36. Retrieved from http://userpages.unikoblenz.de/ diekmann/zfal/zfalarchiv/zfal36_1.pdf

\section{About the Author}

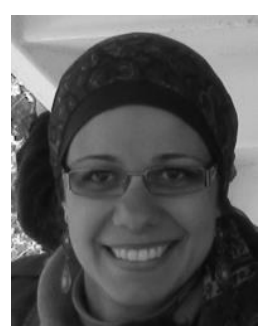

\section{Dr. Marwa Fikry Abdel Samei}

Marwa Fikry Abdel Samei is Assistant Professor of Political Science in the Faculty of Economics and Political Science at Cairo University. She completed her PhD at Northeastern University on public diplomacy in the age of regional media. She is a former EUME fellow at the Forum Transregionale Studien, Berlin, Germany. She is generally interested in modern and contemporary Middle Eastern politics, Islamists and democratization in the Arab World, Arab media, theory of international relations, and international relations in the Middle East. 